\title{
BULLOUS PEMPHIGOID A RARE AUTOIMMUNE DISEASE: A CASE REPORT
}

\author{
S. M. Biradar', S. Dhanavidya'1, P. Kavya'1, T. Keerthi' ${ }^{1}$, N. Sunanda', \\ S. C. Marapur ${ }^{1}$, V. Warad ${ }^{2}$, N. V. Kalyane ${ }^{1}$ \\ 1 - BLDEA'S SSM COLLEGE OF PHARMACY AND RESEARCH CENTER, VIJAYPUR, INDIA \\ 2 - SHRI B. M. PATIL MEDICAL COLLEGE HOSPITAL AND RESEARCH CENTRE, VIJAYPUR, INDIA
}

Background. Bullous pemphigoid (BP) is a rare autoimmune blistering skin disease in the elderly and it is manifested by cutaneous blisters on the skin lesions.

The objective was to emphasize the rare case of $B P$.

Methods. A case report of BP in a 58-year-old male patient admitted to a dermatology ward is presented.

Results. A 58-year-old male patient with complaints of fluid-filled skin lesions, was examined initially over the trunk, gradually progressed involving B/L upper and lower extremities. Even though the patient was treated with the recommended therapy of corticosteroid (Dexamethasone) along with adjuvant drugs, new skin lesions continued to develop, and the patient's condition worsened. The Prednisolone was started in place of Dexamethasone on the fifth day of treatment at its higher dose (50mg/day), the Prednisolone proved its efficacy to combat the extensive condition of $B P$.

Conclusions. Bullous pemphigoid is a distressing blistering skin disease. Untreated disease is often fatal because of the susceptibility to infection and fluid-electrolyte disturbances. The mortality of patients with bullous pemphigoid has been significantly reduced with the advent of new therapies and treatment modalities. The treatment with systemic and topical corticosteroids forms the mainstay of treatment along with other adjuvant drugs. In the present case study, the use of Prednisolone has proven its efficacy in the extensive disease state of $B P$ and improved the patient's quality of life.

KEY WORDS: Bullous Pemphigoid; rare autoimmune disease; Dexamethasone; Prednisolone.

\section{Introduction}

Bullous pemphigoid (BP) is a rare autoimmune blistering disease and affects the elderly mostly. However, on rare occasions, it may affect children and young adults too. The annual incidence of BP has been estimated to range from 2 to 14 new cases per one million people. Its incidence is expected to rise as a consequence of population aging. A recent study in France has established a 3-time increase in the annual incidence of BP over the last 15 years with 21.7 new cases per million inhabitants [1]. Although several clinical variants have been recognized, BP usually presents with tense blisters arising on healthy or erythematous skin, typically involving the flexor surfaces. Autoantibodies against well-characterized autoantigens, BP180 and BP230, are believed to play a crucial role in the pathogenesis of BP. The prognosis of BP has been studied by

Corresponding author: Dr. S M. Biradar, Dept. of Pharm. D Programmee, BLDEAs'SSM College of Pharmacy and Research Centre, Vijauypur-586103, India.

E-mail:smbiradar@rediffmail.com several research groups, but the results of the studies have been inconsistent [2]. The body's immune system is confused and makes an antibody (a type of protein used to fight infection) that targets a part of the skin that normally holds it together. The attack on the skin causes blisters (firm, fluid-filled bubbles on the skin) to form. This disease most often involves only the skin, but sometimes it may affect to eyes, mouth, and genital organs. The following clinical variants are described: classic (described above), localized, nodular, vegetating, erosive, erythrodermic, juvenile and drug-induced [3].

The clinical presentation of BP is tense blisters, which are often seen on erythematous or normal-looking skin of limbs and trunk and may be widespread or localized. Bullae and/or erosions may be present in the oral and genital mucosa. Pruritus alone or associated with erythema and/or urticated plaques may precede the formation of bullae by weeks or months; in some cases, bullae may not become clinically apparent [4]. A recent study conducted in the 
United Kingdom found an incidence of 4.3 (95\% confidence interval (95\% CI), 4.0-4.6) per 100,000 person-years [5]. The BP patients have complex co-morbidity profiles, most notably neurological disorder, as well as autoimmune and are prone to infection. Various studies have confirmed a strong association between BP and neurological disorders [6].

\section{Case study}

A 58-year-old male patient admitted to a dermatology ward with chief complaints of fluid-filled skin lesions (Fig. 1), initially over the trunk, gradually progressed involving bilateral upper and lower extremities. The lesions did not rupture spontaneously and were associated with mild itching. Upon admission, general physical examination was performed in which the patient was moderately built and nourished, conscious and co-operative. Blood pressure was $80 / 60 \mathrm{~mm} \mathrm{Hg}$. Local examination of the skin was performed. It showed that multiple tense vesicles and bullae over the trunk, on both sides upper and lower extremities, few erosions, Nikolsky's sign, and bulla signs had spread. The initial blood investigation revealed total count (TC) 19970 cells $/ \mathrm{mm}^{3}$, neutrophils $57.4 \%$, lymphocytes $15.5 \%$, eosinophils $24.5 \%$, monocytes $2.3 \%$, basophils $0.3 \%$, RBC 5.05 $\times 10^{12} / \mathrm{l}, \mathrm{Hb} 15.0 \mathrm{~g} / \mathrm{dl}$, Packed Cell Volume 45.3\%, MCV 89.7 fl, MCH 29.7 pg, MCHC $33.1 \%$, platelet count 240000 cells $/ \mathrm{mm}^{3}$, ESR $10 \mathrm{~mm} /$ hour.

Initially, dexamethasone IV and oral were prescribed along with other drugs: Ranitidine, Calcimax (Calcium+ Vitamin $\mathrm{D}_{3}+$ Magnesium + Zinc) and Teczine (Levocetirizine). In two days, a few new lesions occurred, then tablet CefiXL (Cefixime+Cloxacillin) $200 \mathrm{mg}$ was prescribed. In 24 hours, multiple new lesions occurred again, then Omnacortil (Prednisolone) (higher dose) - a corticosteroid, was prescribed. GV Iotion (Gentian Violet) and Ointment liquid

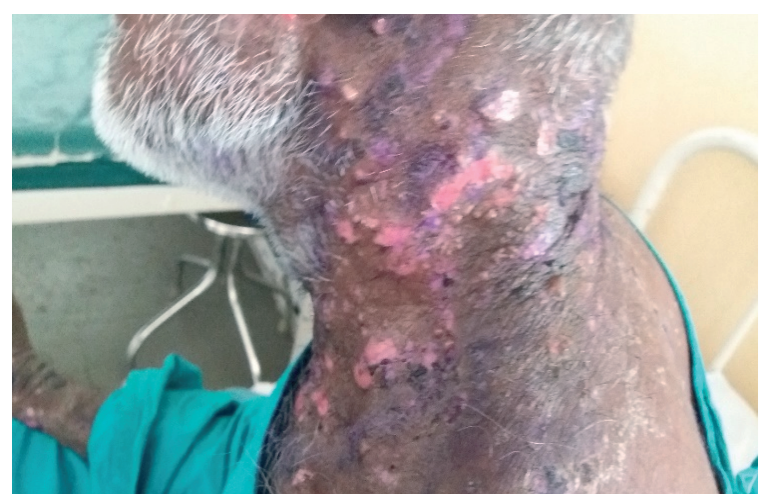

Fig. 1. Skin lesions of Bullous pemphigoid. paraffin were prescribed twice a day (BID), as well as tablet Dapsone (Dapsone) once daily (OD) and Capsule Nicoglow (Nicotinic acid) BID. Treatment was continued up to the time of discharge and the patient condition improved.

\section{Discussion}

Bullous pemphigoid is a rare autoimmune blistering disease; it typically affects the elderly and is followed by significant morbidity and mortality [7]. The clinical symptoms of the disease are development of oral lesions in about one-third of the patients; lesions may occur on the trunk, extremities, and intertriginous areas. In most of the cases, no clear precipitating factors are identified; some precipitating factors are exposure to ultraviolet light, radiation therapy and exposed to certain drugs like furosemide, penicillin, sulfasalazine, and captopril [7]. The disease is characterized by the formation of IgG auto antibodies targeting dystonin (bullous pemphigoid antigen 1 (BPAG1), and /or type XVII collagen also called bullous pemphigoid antigen 2 (BPAG2), which is a component of hemidesmosomes [2]. In the present case fluid-filled lesions were seen initially over the trunk and gradually progressed involving lower and upper extremities.

The recommended treatment for BP is as follows [8]:

Initial therapy. Initial therapy is determined by the extent and rate of progression of the lesions. The priority is to control lesions usually in a slowly progressive form of the disease; initial treatment includes intralesional injections of corticosteroids or topical applications of corticosteroids.

Maintenance therapy. Once most lesions are healed, the dose and type of medication are gradually reduced to limit the risk of side effects. Understanding the rate of dose reduction is determined by clinical response and overall disease activity. It is important to monitor this balance and limit use of unnecessary medication as many fatalities are related to complications associated with the therapy.

The available treatments work via different mechanisms. Some aim to suppress the inflammatory process e.g. corticosteroids, antibiotics, anti-inflammatory mediators. Immune modulating treatments include intravenous immunoglobulins. Intravenous immunoglobulin has been widely tried as an immunomodulatory agent in various auto-antibody mediated blistering diseases. 
Systemic corticosteroids are most commonly used: Dexamethasone and Prednisolone. Typical recommendations for wide spread disease are for a starting daily dose of about $1 \mathrm{mg} / \mathrm{kg}$ continued until cessation of new blister formation then gradually decreased. The starting dose ranges between 40 and $80 \mathrm{mg}$ daily, usually $60 \mathrm{mg}$ daily. Lower starting doses of 20 to $40 \mathrm{mg}$ daily have been recommended. Antibiotics should be considered as the first line of treatment for both localized and mild to moderate disease. Antibiotic treatment is provided for at least 2 weeks. Azathioprine and methotrexate are also recommended [8].

In the present case study, the patient was prescribed with Dexamethasone initially for four days, even though a few new lesions developed. In the next consecutive days the Dexamethasone was replaced with Prednisolone at its higher dose, and then the patients' condition improved. Similar kind of results was noticed with Prednisolone prescription in the extensive disease state of BP [7]. Dapsone was given in one week after patient's admission as it was an immunosuppressant to reduce the action of auto-antibodies and nicotinamide was given on the last two days as it had some effects in reducing itching and redness.

\section{Conclusions}

Bullous pemphigoid is a distressing blistering skin disease. Untreated, Bullous pemphigoid is often fatal because of the susceptibility to infection and fluid-electrolyte disturbances, hence utmost importance is given for BP treatment. The mortality of patients with bullous pemphigoid has been significantly reduced with the advent of new therapies and treatment modalities. The treatment with systemic and topical corticosteroids forms the mainstay of treatment of BP along with other adjuvant drugs. In the present case study, the use of Prednisolone has proven its efficacy in the extensive disease state of BP and improved the patient's quality of life.

\title{
БУЛЬОЗНИЙ ПЕМФІГОЇД - РІДКІСНЕ АВТОІМУННЕ ЗАХВОРЮВАННЯ (КЛІНІЧНИЙ ВИПАДОК)
}

\author{
S. M. Biradar ${ }^{1}$, S. Dhanavidya ${ }^{1}$, P. Kavya ${ }^{1}$, T. Keerthi ${ }^{1}$, N. Sunanda ${ }^{1}$, \\ S. C. Marapur ${ }^{1}$, Vijaykumar Warad ${ }^{2}$, N. V. Kalyane ${ }^{1}$ \\ 1 - BLDEA'S SSM COLLEGE OF PHARMACY AND RESEARCH CENTER', VIJAYPUR, INDIA \\ 2 - SHRI B. M. PATIL MEDICAL COLLEGE HOSPITAL AND RESEARCH CENTRE², VIJAYPUR, INDIA
}

Вступ. Бульозний пемфігоїд (БП) - це рідкісне автоімунне захворювання шкіри у літніх людей, яка проявляється епідермальними пухирями на пошкоджених шкірних покривах.

Мета - акцентувати увагу на рідкісному випадку БП.

Методи дослідження. Представлено клінічний випадок БП у 58-річного пачієнта-чоловіка, який поступив у дерматологічне відділення.

Результати дослідження. Обстежено 58-річного пацієнта із скаргами на заповнені рідиною утвори на шкіри, які з'явилися спочатку на тулубі, і поступово прогресували, поширюючись білатерально на верхні та нижні кінцівки. Незважаючи на те, що пацієнт отримував рекомендовану терапію на базі кортикостероїду (дексаметазон) разом з ад'ювантними препаратами, икірні елементи та пошкодження шкіри прогресували, і стан хворого погіршився. Було застосовано преднізолон замість дексаметазону на п'ятий день лікування у більш високій дозі (50 мг/добу). Останній довів свою ефективність для боротьби з прогресуючим БП.

Висновки. Бульозний пемфігоїд - хронічне, набуте аутоімунне захворювання. Нелікована хвороба часто смертельна через схильність до інфекцій та порушення водно-електролітного обміну. Смертність пацієнтів з бульозним пемфігоїдом значно зменшилася з появою нових методів терапії. Базисним є лікування системними і топічними кортикостероїдами У цьому дослідженні застосування преднізолону довело свою ефективність при генералізованій формі захворювання та дозволило поліпшити якість життя пацієнта.

КЛЮЧОВІ СЛОВА: бульозний пемфігоїд; рідкісні аутоімунні захворювання; дексаметазон; преднізолон. 


\section{References}

1. Teixeira VB, Cabral R, Brites MM, Vieira R, Figueiredo A. Bullous pemphigoid and comorbidities: a case-control study in Portuguese patients. Anais brasileiros de dermatologia. 2014 Apr;89(2):274-8.

2. Kjellman P, Eriksson H, Berg P. A retrospective analysis of patients with bullous pemphigoid treated with methotrexate. Archives of dermatology. 2008 May 1;144(5):612-6.

3. Zanella RR, Xavier TA, Tebcherani AJ, Aoki V, Sanchez AP. Bullous pemphigoid in younger adults: three case reports. Anais Brasileiros de Dermatologia. 2011 Apr;86(2):355-8.

4. Venning VA, Taghipour K, Mustapa MM, Highet AS, Kirtschig G. British Association of Dermatologists' guidelines for the management of bullous pemphigoid 2012. British Journal of Dermatology. 2012 Dec 1;167(6):1200-14.
5. Bastuji-Garin S, Joly $P$, Lemordant $P$, Sparsa A, Bedane C, Delaporte E, Roujeau JC, Bernard P, Guillaume JC, Ingen-Housz-Oro S, Maillard H. Risk factors for bullous pemphigoid in the elderly: a prospective case-control study. Journal of Investigative Dermatology. 2011 Mar 1;131(3):637-43.

6. Liu YD, Wang YH, Ye YC, Zhao WL, Li L. Prognostic factors for mortality in patients with bullous pemphigoid: a meta-analysis. Archives of dermatological research. 2017 Jul 1;309(5):335-47.

7. Varytimiadis D, Sotiriou E, Trigoni A, Ioannides $D$. Successful full clinical remission of bullous pemphigoid with intravenous pulse methylprednisolone and cyclophosphamide: a case report. Aristotle University Medical Journal. 2012 Apr 28;39(1):35-8.

8. Bower C. Bullous pemphigoid: guide to diagnosis and treatment. Prescriber. 2006 Jun 19;17(12): 44-50.

Received: 2018-06-26 